Monica Grazieli CORRÊA(a) Suzana Peres PIMENTEL(a) Fernanda Vieira RIBEIRO(a) Fabiano Ribeiro CIRANO(a) Marcio Zaffalon CASATI(a)

(a) Universidade Paulista - UNIP, School of Dentistry, Dental Research Division, São Paulo, SP, Brazil.
Declaration of Interests: The authors certify that they have no commercial or associative interest that represents a conflict of interest in connection with the manuscript.

Corresponding Author: Marcio Zaffalon Casati E-mail:mzcasati@gmail.com

htpps://doi.org/10.1590/1807-3107bor-2019.vol33.0066

Submitted: June 11, 2019

Accepted for publication: June 13, 2019

Last revision: June 17, 2019

\section{Host response and peri-implantitis}

Abstract: Considering the absence of predictable and effective therapeutic interventions for the treatment of peri-implantitis, scientific evidence concerning the host response profile around dental implants could be important for providing in the future a wider preventive and/or therapeutic window for this peri-implant lesion, indicating biomarkers that provide quantifiable measure of response to peri-implant therapy. Moreover, a better knowledge of pattern of host osteo-immunoinflammatory modulation in the presence of peri-implantitis could either benefit the early diagnostic of the disease or to cooperate to prognostic information related to the status of the peri-implant breakdown. Finally, new evidences concerning the host profile of modulators of inflammation and of osseous tissue metabolism around dental implants could explain the individual susceptibility for developing peri-implant lesions, identifying individuals or sites with increased risk for peri-implantitis. The focus of this chapter was, based on a systematically searched and critically reviewed literature, summarizing the existing knowledge in the scientific research concerning the host osteo-immunoinflammatory response to the microbiological challenge related to periimplantitis.

Keywords: Peri-Implantitis; Dental Implants; Mucositis.

\section{Introduction}

Although dental implants present predictable outcomes and characterize a procedure often performed in daily clinical practice for oral rehabilitation, the development and progression of peri-implantitis has expressively impaired implant survival and success. ${ }^{1,2,3}$ In this context, Derks and Tomasi ${ }^{4}$ reported in a meta-analyses study that weighted implant-based prevalence for peri-implantitis were $22 \%$ (95\%CI: 14-30), whereas another meta-analysis recognized that weighted implant and patient-based peri-implantitis prevalences achieved 9.25\% (95\%CI: 7.57-10.93) and 19.83\% (95\%CI: 15.38-24.27), respectively. ${ }^{5}$ In addition, recently, a multi-level cross-sectional investigation pointed-out that $9.2 \%$ of implants (95\%CI: $4.7-13.7)$ and $19.1 \%$ of patients (95\%CI: 12.6-25.5) presented peri-implantitis. ${ }^{3}$

It is well recognized that peri-implantitis is an inflammatory disease that promotes soft tissue inflammation and also progressive bone loss beyond biological osseous remodeling. ${ }^{6,7}$ Importantly, it has been evidenced that the presence of periodontopathogens is necessary but not sufficient for peri-implantitis initiation and previous data noticeably 
showed that osteo-immunoinflammatory mediators produced by the host response exert an essential impact on peri-implant tissue breakdown. ${ }^{8,9,10,11,12,13,14}$

Considering the absence of predictable and effective therapeutic interventions for the treatment of peri-implantitis, ${ }^{15,16}$ scientific evidence concerning the host response profile around dental implants could be important for providing in the future a wider preventive and/or therapeutic window for this peri-implant lesion, indicating biomarkers that provide quantifiable measure of response to peri-implant therapy. Moreover, a better knowledge of pattern of host osteo-immunoinflammatory modulation in the presence of peri-implantitis could either benefit the early diagnostic of the disease or to cooperate to prognostic information related to the status of the peri-implant breakdown. Finally, new evidences concerning the host profile of modulators of inflammation and of osseous tissue metabolism around dental implants could explain the individual susceptibility for developing peri-implant lesions, identifying individuals or sites with increased risk for peri-implantitis.

The focus of this chapter was, based on a systematically searched and critically reviewed literature, summarizing the existing knowledge in the scientific research concerning the host osteoimmunoinflammatory response to the microbiological challenge related to peri-implantitis.

\section{Host response in patients with peri-implantitis}

\section{Host response to the bacterial challenge in peri-implant lesions}

The understanding that microorganisms exert essential influence on the establishment of periimplantitis is well recognized and the cause-related effect between

biofilm deposition and peri-implant lesions development has been supported by experimental and clinical studies. ${ }^{17,18,19,20}$ Peri-implant tissue collapse involves a intricate and organized microbiota, narrowly approximating that observed in chronic periodontitis. ${ }^{21,22}$ However, as described by Berglundh et al. ${ }^{23}$ based on data from experimental investigations, ${ }^{24,25}$ in peri-implantitis the inflammatory connective tissue infiltrated surrounding implants prolonged to the alveolar bone crest and was related to elevated density of osteoclastogenic cells when compared to natural teeth.

Noteworthy, the individual host response to the microbiological challenge has a deep impact on the establishment and development of peri-implant lesions. Based in this concept, mainly the peri-implant sulcus fluid and saliva has been investigated for diverse molecules associated with inflammatory pattern, bone turnover and proteinases. ${ }^{14,26,27,28,29,30}$

\section{Modulation of host osteo-immunoinflammatory mediators in peri-implantitis}

\section{Pro- and anti-inflammatory mediators}

Interleukin-1 (IL-1) is a chief pro-inflammatory cytokine produced essentially by macrophages but also by neutrophilic granulocytes and other cells. $^{26,27}$ Tumor necrosis factor (TNF)- $\alpha$ is another pro-inflammatory marker that promote stimulation of several events, including alveolar bone loss. ${ }^{31}$ The destructive role of these mediators is well known in the presence of periodontitis ${ }^{26,31}$ and studies also demonstrate augmented production of IL-1 and TNF- $\mathrm{a}$, in the manifestation of peri-implantitis. ${ }^{32,33,34,35,36}$ In this context, a meta-analysis showed that both TNF- $\alpha$ and IL-1 $\beta$ in crevicular fluid of peri-implant pockets might be utilized to determine the early diagnosis of peri-implantitis. ${ }^{36}$ Most investigations described up-regulation of IL-1 $\beta$ in mucositis and peri-implantitis. ${ }^{37,38}$ Additional evidences confirmed that the levels of IL-1 was positively correlated to failing dental implants at the patient and site level, showing a precise profile of host response in patients with peri-implant collapse. ${ }^{39}$ Moreover, IL-1 $\beta$ was reported as a promising candidate in differentiating peri-implantitis from healthy implants. ${ }^{40}$ Other crosssectional data demonstrated that IL- $1 \beta$ and IL-8 were significantly up-regulated in the peri-implant crevicular fluid from subjects with peri-implantitis. ${ }^{41}$

In line, Schminke et al., ${ }^{42}$ that studied the gene and protein expression profiles of peri-implantitis osseous tissue when compared to healthy bone 
tissue, reported up-regulation of the inflammatory marker IL-8 in inflamed tissues, whereas the antiinflammatory molecule PPAR $\gamma$ was reduced in periimplantitis. Concentrations of the anti-inflammatory cytokine IL-10 have also been mentioned to decline in peri-implantitis. ${ }^{43}$ Of interest, Ata-Ali et al. demonstrated augmented levels of IL-1 $\beta /$ IL-10 ratio in patients with peri-implant disease when compared to the healthy peri-implant sites.

IL-17, whose immune response is mediated by $\mathrm{T}$ helper 17 (Th17) cells, is another pro-inflammatory molecule that intercedes numerous biological inflammatory actions including neutrophil and macrophage recruitment and stimulation of other pro-inflammatory mechanisms. ${ }^{44}$ In this context, IL-23 exert a crucial role in intensifying Th17 responses. Conversely, Treg cells, characterized by the elevated expression of suppressive cytokines as transforming growth factor (TGF)- $\beta$, exert regulatory functions. ${ }^{45}$ Interestingly, a recent study investigating the IL-17, IL-23, and TGF- $\beta$ gene expression levels in healthy and diseased peri-implant tissues showed a predominant Th17 response and a diminution of Treg response in the presence of peri-implantitis when compared to peri-implant healthy condition, especially caused by the up-regulation of IL-23 and down-regulation of TGF- $\beta$ observed in peri-implantitis tissues. ${ }^{46}$ Importantly, a systematic review of Duarte et al., ${ }^{47}$ aimed to define if cytokine levels in the fluid around implants could be employed to differentiate healthy implants and those with peri-implantitis, pointed-out that most of studies include in the review described statistically significantly augmented concentration of pro-inflammatory mediators in the peri-implant fluid of dental implants with peri-implantitis than in the peri-implant crevicular fluid of healthy implants, whereas many investigations did not find any significant differences in the peri-implant crevicular fluid levels of anti-inflammatory cytokines.

More recently, however, an interesting crosssectional study examining the biomarker profile (using a large panel of 20 analytes potentially related to pathogenesis of peri-implantitis) in peri-implant crevicular fluid from healthy and implants with periimplantitis confirmed that local biomarkers might contribute to distinguish peri-implant health from disease. ${ }^{14}$ According to the logistic models from this study ${ }_{1}^{14}$ the combination of six biomarkers (Flt-3L, GM-CSF, IL10, sCD40L, IL-17 and TNF-a) augmented noticeably the diagnostic capacity of the model compared to the presence isolated of biomarkers. In addition, among the 20 local molecules analyzed, IL-10, IL-15, IL-17, IL-1 receptor antagonist (IL-1ra), Fms-like tyrosine kinase-3 ligand (Flt-3L), T-cell modulators: soluble human CD40 ligand (sCD-40L), granulocyte-macrophage colony stimulating factor (GM-CSF), TNF- $\alpha$ and platelet-derived growth factor BB (PDGF-BB), were found in at least $13 \%$ of the best-fit models, indicating that these analytes could be further studied as probable diagnostic mediators of peri-implantitis.

\section{Matrix metalloproteinases}

Modifications in the individual pattern of the host response in peri-implant crevicular fluid may also impact the levels of matrix metalloproteinases (MMPs), such as MMP-1, MMP-7 and MMP-8. 29,38,42,48,49 MMPs, especially MMP-8 that is recognized to be the main MMP in periodontitis, exert a vital action in numerous tissues damaging inflammatory processes by destructing extracellular matrix and basement membrane components. MMP-8, or collagenase-2, was described as an early sign of peri-implant breakdow $\mathrm{n}^{50}$ and related to the development of experimental mucositis around implants in response to plaque deposition ${ }^{51}$. Thierbach et al. ${ }^{29}$ and Ramseier et al. ${ }^{38}$ also supported that MMP-8 levels are up-regulated in dental implants diagnosed with peri-implantitis. Other cross-sectional findings revealed that augmented MMP-8 concentrations in peri-implant crevicular fluid may indicate the active phase of the inflammatory peri-implant disease $\mathrm{e}^{48}$ and that MMP-8 is the main collagenase in active periimplantitis. ${ }^{52}$ In line, Irshad et al. ${ }^{53}$ also sustained that up-regulation of inflammatory mediators, including MMP-1, in fibroblasts from peri-implantitis sites in response to $P$. gingivalis may exert a relevant impact in the pathogenesis of peri-implantitis.

A relevant aspect to be highlighted concerning the impact of MMPs in the peri-implant tissues is that the activities of these enzymes are blocked by tissue inhibitors of matrix metalloproteinases 
(TIMPs). ${ }^{54}$ Interestingly, evidence indicated that fibroblasts from peri-implantitis granulation tissue showed up-regulation of mRNA MMP-1 and reduced gene expression for TIMP-1 when compared to cells collected from chronic periodontitis granulation tissue. ${ }^{55}$ Additional evidence suggested that reduced MMP-1/TIMP-1 levels could be an indicator of loss of clinical attachment around dental implants, ${ }^{38}$ although complementary research should be directed to examine MMP-1 bound to TIMP-1 as a prognostic marker for the peri-implant diseases.

\section{Bone resorption/remodeling mediators}

Importantly, in the presence of lesions around dental implants, the up-regulation of pro-inflammatory markers and metalloproteinases in the peri-implant tissues can also induce the chemotaxis of active osteoclasts, modifying the patter of expression of bone resorption/remodeling mediators around the implants. ${ }^{11,30}$ In this context, earlier data from a cross-sectional study showed increased amount of C-telopeptide pyridinoline crosslinks of type I collagen (ICTP) in the peri-implant fluid of implants with peri-implantitis, suggesting that augmented type I collagen breakdown and bone resorption in these sites ${ }^{11}$, although Tümer et al. ${ }^{56}$ have not confirmed significant ICTP level changes in the peri-implant sulcular fluid of dental implants with or without peri-implant bone destruction.

In their study, Arikan et al. ${ }^{11}$ also demonstrated that significantly lower OPG and increased soluble RANKL concentrations in the peri-implantitis sites than the healthy control sites. In addition, the authors reported that RANKL/OPG ratio was increased in peri-implantitis compared with the clinically healthy implants, supporting the negative impact of peri-implantitis on alveolar bone resorption. ${ }^{11}$ In line, Rakic et al. ${ }^{13}$ demonstrated that not only concentrations of RANK, sRANKL and OPG were significantly augmented in patients with periimplantitis compared with those with healthy periimplant tissues, but also sclerostin levels, a marker recognized to leads to decreased bone formation. According to these findings, RANKL, OPG, and sclerostin may be suggested as prognostic biomarkers in peri-implantitis.
Remarkably, Che et al. ${ }^{30}$ revealed that osteopontin (OPN) may exert a crucial role for IL-1 $\beta$ production and apoptosis in peri-implantitis, as evidenced by the investigation of patient's peri-implant crevicular fluid and cell-culture experiments, reducing inflammation by down-regulation of pro-inflammatory cytokines in peri-implantitis. In fact, OPN is an osteo-immunoinflammatory marker related to both bone development and mineralization and also in infective inflammation as an immune modulator by regulating cytokine production. ${ }^{57,58}$ However, the role of osteo-immunoinflammatory mediators, as OPN, in peri-implantitis is not well understood and additional investigations would be important to improve this knowledge.

In their study, Schminke et al., ${ }^{42}$ investigating the molecular configuration of healthy and periimplantitis bone tissues with the help of a microarray, as well as qPCR and Western blotting, demonstrated that BMPs such as BMP-7 were down-regulated in inflamed bone tissues when compared to periimplant healthy tissues. According to the authors, the osteogenic transcription factor RUNX2 was reduced, in agreement with the collapse course of the bone during peri-implantitis.

Additionally, representative bone matrix biomarkers, as SPP1, BGLAP, and COL9A1, were decreased in the peri-implantitis bone tissues, while enhanced expression of fibrocyte markers were detected. Accordantly, earlier evidences have already showed that fibroblasts contribute to the pathogenesis of peri-implantitis up-regulating both vascularity and matrix degradation. ${ }^{55}$ Further, marginal bone breakdown in initial experimental diseases may encourage an imbalanced host response, which is also suggested to promote the stimulation of fibroblasts. ${ }^{59}$

Other molecules recently mentioned in the literature by interfering in the pathogenesis of peri-implantitis are semaphorins, ${ }^{60}$ a class of cell surface proteins related to inflammatory pathways also involved in the regulatory mechanisms of bone metabolism. ${ }^{61}$ According to Bastos et al., ${ }^{60}$ that investigated the gene expression of semaphorins $3 \mathrm{~A}, 3 \mathrm{~B}, 4 \mathrm{~A}$, and $4 \mathrm{D}$ in peri-implant tissue biopsy from healthy and diseased dental implants, it was identified that peri-implantitis sites presented 
augmented mRNA levels of Sem3A and Sem4D and reduced expression of Sem4A when compared to peri-implant healthy tissues. Considering that is the first investigation evaluating the role of semaphorins in peri-implant lesions, further data are required to clarify the involvement of these molecules in the peri-implantitis.

\section{Oxidative stress biomarkers}

Besides the peri-implant breakdown be attributed to the modulation of numerous cyto/chemokines in favour of a pro-inflammatory host response profile, ${ }^{37,38}$ it could be also related to oxidative stress mechanisms and excessive production of reactive oxygen species which also exert a vital impact in the host response. In this context, Sánchez-Siles et al. ${ }^{28}$ investigated, in a transversal study, salivary concentration of oxidative stress molecules in individuals with periimplantitis. The outcomes from this study revealed that patients with implants (four to five) diagnosed with peri-implantitis do not display high salivary malondialdehyde (MDA), a key lipid peroxidation by-product, ${ }^{62}$ and myeloperoxidase (MPO), the only peroxidase that catalyzes the alteration of hydrogen peroxide and chloride to hypochlorous acid concentrations. ${ }^{63}$ It suggestes that peri-implantitis does not promote quantifiable oxidative impairment in saliva. However, additional prospective studies in patients with a greater number of dental implants with peri-implantitis could be important to clarify the real impact of peri-implantitis in the levels of oxidative stress molecules in saliva.

\section{The role of host genetic susceptibility for peri-implantitis}

It is noteworthy, studies have elucidated whether the host genetic susceptibility regulates the vulnerability for biological complication of dental implants. Some investigations suggest that IL-1 genotype may be associated with augmented predisposition to peri-implant tissue breakdown. ${ }^{64,65,66}$ Although, in a systematic review, Dereka et al. ${ }^{67}$ have concluded that there is no clear connection between biological complications, such as early dental implant loss, and precise genetic polymorphisms of IL-1, IL-2, IL-6, TGF- $\beta$ or TNF- $\alpha,{ }^{68,69,70,71}$ the authors revealed that a propensity may be highlighted demonstrating a possible association between IL-1 genotype and peri-implantitis. ${ }^{67}$ In agreement with these data, Shimpuku et al. ${ }^{72}$ suggested that a specific genetic polymorphism (IL-1B-511 2/2 genotype) of the IL-1 gene was related to early marginal peri-implant bone loss.

Remarkable, a polymorphism in the MMP-1 promotor (G-1607GG), recognized to lead augmented transcriptional activity, was reported to be related to dental implant failure. ${ }^{73}$ Other researchers demonstrated that TNFa -308 A/G and CD14-159 C/T polymorphisms are related to peri-implantitis and could contribute as markers related to peri-implantitis. ${ }^{74}$ In line, recently, Petkovic-Curcin et al. ${ }^{75}$ also suggested that the occurrence of TNFa-308 GA/AA genotypes could augment the risk for peri-implantitis lesions, whereas, conversely to Rakic et al. ${ }^{76}$ findings, CD14-159 polymorphic CT/TT genotypes have reduced the risk.

Supplementary data in greater samples and in different population are required to support these findings.

\section{Altered peri-implant host response in patients at risk conditions}

It is important to highlight that a noticeable number of patients submitted to dental implants therapy are individuals at risk conditions to develop worsened host osteo-immunoinflammatory response to the pathogens related to peri-implantitis, such as smoking and diabetic patients. Thus, in these patient profiles, a bacterial challenge in combination with an exacerbated or altered host reaction may more easily or pronouncedly contribute to the advance of peri-implant tissue destruction.

Although clinical trials reporting dental implant success in type 2 diabetic individuals with well-controlled glycaemia and unknown or compromised glycaemic status have demonstrated varying failure rates without a defined relation to glycaemic control, ${ }^{77,78,79,80,81}$ it has been established that poor glycaemic status is the most relevant factor affecting the rates of implant complications (including peri-implant bone loss) in diabetics. ${ }^{82}$ 
Is well known that diabetic patients have an augmented risk of developing periodontitis, and that the poor glycaemic status may negatively modulate immunoinflammatory mediators in the gingival crevicular fluid, ${ }^{80}$ leading to periodontal attachment and tooth loss over time. ${ }^{83}$ Moreover, diabetes has also been suggested as a biological factor related to peri-implant diseases ${ }^{84,85}$ and, in addition, data have indicated that the poor glycaemic control may promote an overproduction of the proinflammatory biomarkers, in the presence of peri-implantitis. ${ }^{86}$

According to Al-Sowygh et al. ${ }^{87}$ that evaluated the concentrations of advanced glycation end products (AGEs) in peri-implant crevicular fluid of type 2 diabetes mellitus patients with different glycemic control, higher AGEs levels were also detected in patients with elevated glycemic status, suggesting that AGEs may be considered as probable biomarker of inflammation in diabetic subjects with periimplantitis, which could modify bone physiology, troubling remodeling and promoting bone loss. ${ }^{88}$. Moreover, another recent study evidenced that the levels of AGEs in peri-implant sulcular fluid were also increased in patients presenting prediabetes. ${ }^{89}$. In line, Venza et al. ${ }^{86}$ verified that type 2 diabetic patients with poorly controlled glycaemic status showed overexpression of TNF- $\alpha$ and IL-8 in sites with peri-implantitis when compared to patients with normoglycaemic and well-controlled diabetes. Altogether, these data indicate that the balance between immunoinflammatory mediators in the peri-implant fluid of patients with diabetes would be shifted towards a state of hyperinflammatory characteristics, especially when glycaemic control is poor, which could create an at-risk-for-harm environment for a peri-implant tissue breakdown over time.

It is relevant to note that TNF- $\alpha$ acts synergistically with IL-1 $\beta$ to start essential mediators of inflammatory cascade (Duarte et al. 2009), and these molecules are considered the two most relevant in osteoclast formation and bone resorption..$^{90}$ In line, it was previously reported significantly augmented bone loss prevalence in peri-implantitis sites from poorly controlled than well-controlled diabetics or healthy patients $(60.2 \%$ vs $46.3 \%$ vs $45.5 \%) .{ }^{86}$
Noteworthy, Ghiraldini et al., ${ }^{91}$ that evaluated the influence of glycaemic in the local release of bone-related factors during the peri-implant bone healing, displayed that key osteogenic and/or bone mineralization molecules were decreased in poorly controlled diabetic individuals, supporting that diabetics with inadequate glycaemic status have a different local profile of bone markers, which could impair the host reaction during the peri-implant healing course.

Tobacco smoking is another relevant condition that has been described as highly related to altered peri-implant host response in favor of periimplantitis establishment, increasing the prevalence of diseases around dental implants and harmfully inducing the peri-implant bone breakdown. 3,85,92,93 In this context, innumerous studies describe that smoking negatively alters the profile of individual host response and stimulates down-regulation of local osteo-immuno-inflammatory molecules around implants even in non-manifesting inflammation sites, contributing to an augmented predisposition to peri-implant disturbing. ${ }^{94,95,96,97}$

Accordantly, a recent investigation of Akram et al. ${ }^{98}$ supported that higher probing depth and increased crestal bone loss were detected among cigarettesmokers and smokeless-tobacco users when compared to those never exposed to tobacco smoking and, according to the authors, the up-regulation of local pro-inflammatory biomarkers, such as IL-1 $\beta$ and MMP-9, may justify the superior susceptibility of cigarette-smokers and smokeless-tobacco users to peri-implant breakdown. Of interest, waterpipe (narghile) smoking also promotes negative impact on host response and contributes to peri-implantitis establishment. ${ }^{99}$ According to these last authors, waterpipe-smokers presented significantly higher local levels of pro-inflammatory IL-1 $\beta$, IL-6 and TNF- $\alpha$ in the peri-implant fluid when compared to never-smokers in sites with peri-implantitis.

Remarkably, Negri et al.$^{97}$ also pointed-out that smoking habit may modify the local mediators' profile around implants, promoting decreases in TNF- $\alpha$, IL-4, IL-8 and OPG levels and an augmented ICTP and TH1/TH2 ratio in peri-implant crevicular fluid, which appear modulate the bone-related 
molecules towards to osteoclastogenesis situation and create an immunosuppressive scenario even in non-manifesting inflammation sites. Anyway, additional investigations should confirm the impact of smoking in the pathway of interactions among the global net of pro- and anti-inflammatory mediators and bone-related markers on molecular and cellular levels during peri-implantitis.

Although the impact of obesity on host osteoimmunoinflammatory response is yet scarce in the literature, interestingly, Vohra et al., ${ }^{100}$ based in a cross-sectional retrospective study, demonstrated that peri-implant clinical and radiographic conditions are worse in patients with severe obesity, and suggested that this finding may be related to systemic low-grade inflammatory marker (C-reactive protein) that was increased in these patients.

Overall, additional studies are required to provide a better elucidation of the patter of host response related to peri-implantitis in individuals at most vulnerable conditions, which could make easier to predict which patient is at risk for peri-implant complications during maintenance of dental implants.

\section{Impact of degradation products released from dental implants in peri-implant host immunoinflammatory response}

Metal wear particles, as titanium and iron elements, from dental implant surfaces have been observed both in soft and hard peri-implant tissues, ${ }^{101,102}$ and although their impact in the pathogenesis of peri-implantitis and in the host osteo-immunoinflammatory response is still indefinite, some studies have related the presence of these particles to inflammatory processes ${ }^{103,104}$. Tribocorrosion product release from dental implants may be promoted in diverse ways such as by the detachment from the implant surface during its insertion; wear promoted by micro-movements between contacting surfaces at implant/prosthetic connections; by the corrosive impact of therapeutic formulations as fluorides or bleaching substances; and during peri-implantitis therapies such as polishing of the implant surface or implantoplasty. ${ }^{104,105,106,107,108}$

Irshad et al., ${ }^{53}$ in an in vitro investigation, showed that peri-implant granulation tissue fibroblasts challenged with titanium dioxide $\left(\mathrm{TiO}_{2}\right)$ particles in association with viable Porphyromonas gingivalis infection augmented the pro-inflammatory response, up-regulating the gene expression and production of TNF-a. In line, recently, Pettersson et al. ${ }^{109}$ demonstrated in vitro that $\mathrm{Ti}$ ions form particles in cell culture and that the activation and secretion of IL-1 $\beta$ was associated to particles and not to the soluble ions.

Other evidences demonstrated showed that soluble ions, more than particles, are responsible for the proinflammatory response stimulated in monocytes/ macrophages ${ }^{110}$ and by the increasing in the ratio of RANKL/OPG, inducing to the alveolar bone resorption $1{ }^{11}$. In line, Taira et al. ${ }^{112}$ revealed that macrophages cultivated in a medium containing 1 ppm titanium produced $170 \%$ more TNF- $\alpha$ than cells cultivated free of titanium.

Noteworthy, according to Pettersson et al. ${ }^{109}$ in vitro and in vivo findings, leaked Ti ions from a dental implant could be converted into particles in the surrounding tissue and be phagocytized by macrophages, producing a pro-inflammatory peri-implant response which may be significantly potentialized by the presence of bacteria. Despite the current evidence concerning such issues, further investigations are essential to clarify the mechanisms involved in the pathogenesis of peri-implantitis related to the metal particles and wear debris from dental implants.

\section{Final considerations}

In a different way to what has been extensively studied and intensely exposed concerning the treatment of periodontitis, until now no predictable and effective therapeutic intervention has been defined for the treatment of peri-implantitis. ${ }^{15,16}$ Thus, primary prevention of peri-implantitis becomes extremely relevant.

As observed in this review, based on the presented literature, innumerous immunoinflammatory mediators and bone-related molecules could be considered as potential biomarkers to be used in combination with clinical evaluation for monitoring peri-implant health and disease. A probable approach would be to monitor host-derived biomarkers related 
to inflammation, as IL-1 $\beta$, enzymes that degrade extracellular matrix, as MMP-8, simultaneously with bone loss mediators, as RANKL, OPG and sclerostin, whose levels are recognized to be modified in patients with peri-implant diseases and proposed as prognostic biomarkers in peri-implantitis. ${ }^{11,13,29,38}$ The idea of prevention supported by premature detection and systematic maintenance therapy may have a crucial impact on decreasing the occurrence of peri-implant lesions.

Nevertheless, it should be kept in mind that additional data from longitudinal and interventional studies could offer more consistent information on the probable impact of certain immunoinflammatory mediators and bone-related molecules in the pathogenesis of peri-implant diseases. Importantly, individual genetic data might potentially contribute as valuable information during the clinical practice to establish therapeutic planning and prognosis, considering that preventive and management method could be positively coordinated depending on observed genotype. Thus, supplementary evidence concerning the molecular pathophysiology of peri-implant infections may, in the future, benefit the treatment of dental implants presenting peri-implantitis in a long-term basis and cooperate in the development of preventive approaches to avoid peri-implant tissue breakdown establishment.

\section{References}

1. Roos-Jansåker AM, Lindahl C, Renvert H, Renvert S. Nine- to fourteen-year follow-up of implant treatment. Part I: implant loss and associations to various factors. J Clin Periodontol. 2006 Apr;33(4):283-9. https://doi.org/10.1111/i.1600-051X.2006.00907.x

2. Papathanasiou E, Finkelman M, Hanley J, Parashis AO. Prevalence, Etiology and Treatment of Peri-Implant Mucositis and Peri-Implantitis: A Survey of Periodontists in the United States. J Periodontol. 2016 May;87(5):493-501. https://doi.org/10.1902/jop.2015.150476

3. Pimentel SP, Shiota R, Cirano FR, Casarin RC, Pecorari VG, Casati MZ, et al. Occurrence of peri-implant diseases and risk indicators at the patient and implant levels: A multilevel cross-sectional study. J Periodontol. 2018 Sep;89(9):1091-100. https://doi.org/10.1002/JPER.17-0599

4. Derks J, Tomasi C. Peri-implant health and disease: a systematic review of current epidemiology. J Clin Periodontol. 2015 Apr;42 Suppl 16:S158-71. https://doi.org/10.1111/icpe.12334

5. Lee CT, Huang YW, Zhu L, Weltman R. Prevalences of peri-implantitis and peri-implant mucositis: systematic review and meta-analysis. J Dent. 2017 Jul;62:1-12. https://doi.org/10.1016/i.jdent.2017.04.011

6. Heitz-Mayfield LJ. Peri-implant diseases: diagnosis and risk indicators. J Clin Periodontol. 2008 Sep;35(8 Suppl):292-304 https://doi.org/10.1111/i.1600-051X.2008.01275.x

7. Sanz M, Chapple IL. Clinical research on peri-implant diseases: consensus report of Working Group 4. J Clin Periodontol. 2012 Feb;39 Suppl 12:202-6. https://doi.org/10.1111/i.1600-051X.2011.01837.x

8. Monov G, Strbac GD, Baron M, Kandler B, Watzek G, Gruber R. Soluble RANKL in crevicular fluid of dental implants: a pilot study. Clin Implant Dent Relat Res. 2006;8(3):135-41. https://doi.org/10.1111/j.1708-8208.2006.00012.x

9. Strbac GD, Monov G, Cei S, Kandler B, Watzek G, Gruber R. Cathepsin K levels in the crevicular fluid of dental implants: a pilot study. J Clin Periodontol. 2006 Apr;33(4):302-8. https://doi.org/10.1111/i.1600-051X.2006.00904.x

10. Duarte PM, de Mendonça AC, Máximo MB, Santos VR, Bastos MF, Nociti Júnior FH. Differential cytokine expressions affect the severity of peri-implant disease. Clin Oral Implants Res. 2009 May;20(5):514-20. https://doi.org/10.1111/i.1600-0501.2008.01680.x

11. Arikan F, Buduneli N, Lappin DF. C-telopeptide pyridinoline crosslinks of type I collagen, soluble RANKL, and osteoprotegerin levels in crevicular fluid of dental implants with peri-implantitis: a case-control study. Int J Oral Maxillofac Implants. 2011 Mar-Apr;26(2):282-9.

12. Javed F, Al-Hezaimi K, Salameh Z, Almas K, Romanos GE. Proinflammatory cytokines in the crevicular fluid of patients with peri-implantitis. Cytokine. 2011 Jan;53(1):8-12. https://doi.org/10.1016/i.cyto.2010.08.013

13. Rakic M, Lekovic V, Nikolic-Jakoba N, Vojvodic D, Petkovic-Curcin A, Sanz M. Bone loss biomarkers associated with peri-implantitis A cross-sectional study. Clin Oral Implants Res. 2013 Oct;24(10):1110-6. https://doi.org/10.1111/j.1600-0501.2012.02518.x

14. Zani SR, Moss K, Shibli JA, Teixeira ER, Mairink RO, Onuma T, et al. Peri-implant crevicular fluid biomarkers as discriminants of peri-implant health and disease. J Clin Periodontol. 2016 Oct;43(10):825-32. https://doi.org/10.1111/icpe.12586

15. Esposito M, Grusovin MG, Worthington HV. Treatment of peri-implantitis: what interventions are effective? A Cochrane systematic review. Eur J Oral Implantol. 2012;5 Suppl:S21-41. 
16. Jepsen S, Berglundh T, Genco R, Aass AM, Demirel K, Derks J, et al. Primary prevention of peri-implantitis: managing peri-implant mucositis. J Clin Periodontol. 2015 Apr;42 Suppl 16:S152-7. https://doi.org/10.1111/icpe.12369

17. Berglundh T, Lindhe J, Marinello C, Ericsson I, Lilienberg B. Soft tissue reaction to de novo plaque formation on implants and teeth. An experimental study in the dog. Clin Oral Implants Res. 1992 Mar;3(1):1-8. https://doi.org/10.1034/i.1600-0501.1992.030101.x

18. Pontoriero R, Tonelli MP, Carnevale G, Mombelli A, Nyman SR, Lang NP. Experimentally induced peri-implant mucositis. A clinical study in humans. Clin Oral Implants Res. 1994 Dec;5(4):254-9. https://doi.org/10.1034/i.1600-0501.1994.050409.x

19. Albouy JP, Abrahamsson I, Berglundh T. Spontaneous progression of experimental peri-implantitis at implants with different surface characteristics: an experimental study in dogs. J Clin Periodontol. 2012 Feb;39(2):182-7. https://doi.org/10.1111/j.1600-051X.2011.01820.x

20. Ribeiro FV, Casati MZ, Casarin RC, Corrêa MG, Cirano FR, Negri BM, et al. Impact of a triclosan-containing toothpaste during the progression of experimental peri-implant mucositis: clinical parameters and local pattern of osteo-immunoinflammatory mediators in peri-implant fluid. J Periodontol. 2018 Feb;89(2):203-12. https://doi.org/10.1002/JPER.17-0302

21. Rams TE, Roberts TW, Feik D, Molzan AK, Slots J. Clinical and microbiological findings on newly inserted hydroxyapatite-coated and pure titanium human dental implants. Clin Oral Implants Res. 1991 Jul-Sep;2(3):121-7. https://doi.org/10.1034/j.1600-0501.1991.020304.x

22. Augthun M, Conrads G. Microbial findings of deep peri-implant bone defects. Int J Oral Maxillofac Implants. 1997 Jan-Feb;12(1):106-12.

23. Berglundh T, Zitzmann NU, Donati M. Are peri-implantitis lesions different from periodontitis lesions? J Clin Periodontol. 2011 Mar;38 Suppl 11:188-202. https://doi.org/10.1111/j.1600-051X.2010.01672.x

24. Lindhe J, Berglundh T, Ericsson I, Liljenberg B, Marinello C. Experimental breakdown of peri-implant and periodontal tissues. A study in the beagle dog. Clin Oral Implants Res. 1992 Mar;3(1):9-16. https://doi.org/10.1034/i.1600-0501.1992.030102.x

25. Zitzmann NU, Berglundh T, Ericsson I, Lindhe J. Spontaneous progression of experimentally induced periimplantitis. J Clin Periodontol. 2004 Oct;31(10):845-9. https://doi.org/10.1111/j.1600-051X.2004.00567.x

26. Tokoro Y, Yamamoto T, Hara K. IL-1 beta mRNA as the predominant inflammatory cytokine transcript: correlation with inflammatory cell infiltration into human gingiva. J Oral Pathol Med. 1996 May;25(5):225-31. https://doi.org/10.1111/j.1600-0714.1996.tb01376.x

27. Galbraith GM, Hagan C, Steed RB, Sanders JJ, Javed T. Cytokine production by oral and peripheral blood neutrophils in adult periodontitis. J Periodontol. 1997 Sep;68(9):832-8. https://doi.org/10.1902/jop.1997.68.9.832

28. Sánchez-Siles M, Lucas-Azorin J, Salazar-Sánchez N, Carbonell-Meseguer L, Camacho-Alonso F. Salivary Concentration of Oxidative Stress Biomarkers in a Group of Patients with Peri-Implantitis: A Transversal Study. Clin Implant Dent Relat Res. 2016 Oct;18(5):1015-22. https://doi.org/10.1111/cid.12367

29. Thierbach R, Maier K, Sorsa T, Mäntylä P. Peri-Implant Sulcus Fluid (PISF) Matrix Metalloproteinase (MMP) - 8 Levels in Peri-Implantitis. J Clin Diagn Res. 2016 May;10(5):ZC34-8. https://doi.org/10.7860/JCDR/2016/16105.7749

30. Che C, Liu J, Yang J, Ma L, Bai N, Zhang Q. Osteopontin is essential for IL-1 $\beta$ production and apoptosis in peri-implantitis. Clin Implant Dent Relat Res. 2018 Jun;20(3):384-92. https://doi.org/10.1111/cid.12592

31. Graves DT, Cochran D. The contribution of interleukin-1 and tumor necrosis factor to periodontal tissue destruction. J Periodontol. 2003 Mar;74(3):391-401. https://doi.org/10.1902/jop.2003.74.3.391

32. Güncü GN, Akman AC, Günday S, Yamalık N, Berker E. Effect of inflammation on cytokine levels and bone remodelling markers in peri-implant sulcus fluid: a preliminary report. Cytokine. 2012 Aug;59(2):313-6. https://doi.org/10.1016/i.cyto.2012.04.024

33. Kao RT, Curtis DA, Richards DW, Preble J. Increased interleukin-1 beta in the crevicular fluid of diseased implants. Int J Oral Maxillofac Implants. 1995 Nov-Dec;10(6):696-701.

34. Panagakos FS, Aboyoussef H, Dondero R, Jandinski JJ. Detection and measurement of inflammatory cytokines in implant crevicular fluid: a pilot study. Int J Oral Maxillofac Implants. 1996 Nov-Dec;11(6):794-9.

35. Curtis DA, Kao R, Plesh O, Finzen F, Franz L. Crevicular fluid analysis around two failing dental implants: a clinical report. J Prosthodont. 1997 Sep;6(3):210-4. https://doi.org/10.1111/j.1532-849X.1997.tb00093.x

36. Faot F, Nascimento GG, Bielemann AM, Campão TD, Leite FR, Quirynen M. Can peri-implant crevicular fluid assist in the diagnosis of peri-implantitis? A systematic review and meta-analysis. J Periodontol. 2015 May;86(5):631-45. https://doi.org/10.1902/jop.2015.140603

37. Fonseca FJ, Moraes Junior M, Lourenço EJ, Teles Dde M, Figueredo CM. Cytokines expression in saliva and peri-implant crevicular fluid of patients with peri-implant disease. Clin Oral Implants Res. 2014 Feb;25(2):e68-72. https://doi.org/10.1111/clr.12052

38. Ramseier CA, Eick S, Brönnimann C, Buser D, Brägger U, Salvi GE. Host-derived biomarkers at teeth and implants in partially edentulous patients. A 10-year retrospective study. Clin Oral Implants Res. 2016 Feb;27(2):211-7. https://doi.org/10.1111/clr.12566

39. Salcetti JM, Moriarty JD, Cooper LF, Smith FW, Collins JG, Socransky SS, et al. The clinical, microbial, and host response characteristics of the failing implant. Int J Oral Maxillofac Implants. 1997 Jan-Feb;12(1):32-42. 
40. Li JY, Wang HL. Biomarkers associated with periimplant diseases. Implant Dent. 2014 Oct;23(5):607-11. https://doi.org/10.1097/ID.0000000000000129

41. Hall J, Pehrson NG, Ekestubbe A, Jemt T, Friberg B. A controlled, cross-sectional exploratory study on markers for the plasminogen system and inflammation in crevicular fluid samples from healthy, mucositis and peri-implantitis sites. Eur J Oral Implantol. 2015;8(2):153-66.

42. Schminke B, Vom Orde F, Gruber R, Schliephake H, Bürgers R, Miosge N. The pathology of bone tissue during peri-implantitis. J Dent Res. 2015 Feb;94(2):354-61. https://doi.org/10.1177/0022034514559128

43. Casado PL, Canullo L, Filardy AA, Granjeiro JM, Barboza EP, Leite Duarte ME. Interleukins $1 \beta$ and 10 expressions in the periimplant crevicular fluid from patients with untreated periimplant disease. Implant Dent. 2013 Apr;22(2):143-50. https://doi.org/10.1097/ID.0b013e3182818792

44. Ouyang W, Kolls JK, Zheng Y. The biological functions of T helper 17 cell effector cytokines in inflammation. Immunity. 2008 Apr;28(4):454-67. https://doi.org/10.1016/i.immuni.2008.03.004

45. Fietta P, Delsante G. The effector T helper cell triade. Riv Biol. 2009 Jan-Apr;102(1):61-74.

46. Mardegan GP, Shibli JA, Roth LA, Faveri M, Giro G, Bastos MF. Transforming growth factor- $\beta$, interleukin- 17 , and IL-23 gene expression profiles associated with human peri-implantitis. Clin Oral Implants Res. 2017 Jul;28(7):e10-5. https://doi.org/10.1111/clr.12846

47. Duarte PM, Serrão CR, Miranda TS, Zanatta LC, Bastos MF, Faveri M, et al. Could cytokine levels in the peri-implant crevicular fluid be used to distinguish between healthy implants and implants with peri-implantitis? A systematic review. J Periodontal Res. 2016 Dec;51(6):689-98. https://doi.org/10.1111/jre.12354

48. Kivelä-Rajamäki M, Maisi P, Srinivas R, Tervahartiala T, Teronen O, Husa V, et al. Levels and molecular forms of MMP-7 (matrilysin-1) and MMP-8 (collagenase-2) in diseased human peri-implant sulcular fluid. J Periodontal Res. 2003a Dec;38(6):583-90. https://doi.org/10.1034/i.1600-0765.2003.00688.x

49. Kivelä-Rajamäki MJ, Teronen OP, Maisi P, Husa V, Tervahartiala TI, Pirilä EM, et al. Laminin-5 gamma2-chain and collagenase-2 (MMP-8) in human peri-implant sulcular fluid. Clin Oral Implants Res. 2003b Apr;14(2):158-65. https://doi.org/10.1034/j.1600-0501.2003.140204.x

50. Basegmez C, Yalcin S, Yalcin F, Ersanli S, Mijiritsky E. Evaluation of periimplant crevicular fluid prostaglandin E2 and matrix metalloproteinase-8 levels from health to periimplant disease status: a prospective study. Implant Dent. 2012 Aug;21(4):306-10. https://doi.org/10.1097/ID.0b013e3182588408

51. Salvi GE, Aglietta M, Eick S, Sculean A, Lang NP, Ramseier CA. Reversibility of experimental peri-implant mucositis compared with experimental gingivitis in humans. Clin Oral Implants Res. 2012 Feb;23(2):182-90. https://doi.org/10.1111/j.1600-0501.2011.02220.x

52. Arakawa H, Uehara J, Hara ES, Sonoyama W, Kimura A, Kanyama M, et al. Matrix metalloproteinase- 8 is the major potential collagenase in active peri-implantitis. J Prosthodont Res. 2012 Oct;56(4):249-55. https://doi.org/10.1016/i.jpor.2012.07.002

53. Irshad M, Scheres N, Crielaard W, Loos BG, Wismeijer D, Laine ML. Influence of titanium on in vitro fibroblast-Porphyromonas gingivalis interaction in peri-implantitis. J Clin Periodontol. 2013 Sep;40(9):841-9. https://doi.org/10.1111/icpe.12136

54. Verstappen J, Von den Hoff JW. Tissue inhibitors of metalloproteinases (TIMPs): their biological functions and involvement in oral disease. J Dent Res. 2006 Dec;85(12):1074-84. https://doi.org/10.1177/154405910608501202

55. Botero JE, Yepes FL, Roldán N, Castrillón CA, Hincapie JP, Ochoa SP, et al. Tooth and periodontal clinical attachment loss are associated with hyperglycemia in patients with diabetes. J Periodontol. 2012 Oct;83(10):1245-50. https://doi.org/10.1902/jop.2012.110681

56. Tümer C, Aksoy Y, Güncü GN, Nohutçu RM, Kılınç K, Tözüm TF. Possible impact of inflammatory status on C-telopeptide pyridinoline cross-links of type I collagen and osteocalcin levels around oral implants with peri-implantitis: a controlled clinical trial. J Oral Rehabil. 2008 Dec;35(12):934-9. https://doi.org/10.1111/j.1365-2842.2008.01879.x

57. Ram VS, Parthiban, Sudhakar U, Mithradas N, Prabhakar R. Bonebiomarkers in periodontal disease: a review article. J Clin Diagn Res. 2015 Jan;9(1):ZE07-10. https://doi.org/10.7860/JCDR/2015/11268.5438

58. Foster BL, Ao M, Salmon CR, Chavez MB, Kolli TN, Tran AB, et al. Osteopontin regulates dentin and alveolar bone development and mineralization. Bone. 2018 Feb;107:196-207. https://doi.org/10.1016/i.bone.2017.12.004

59. Albrektsson T, Dahlin C, Jemt T, Sennerby L, Turri A, Wennerberg A. Is marginal bone loss around oral implants the result of a provoked foreign body reaction? Clin Implant Dent Relat Res. 2014 Apr;16(2):155-65. https://doi.org/10.1111/cid.12142

60. Bastos MF, de Franco L, Garcia Tebar AC, Giro G, Shibli JA. Expression Levels of Semaphorins 3A, 3B, 4A, and 4D on Human Peri-implantitis. Int J Oral Maxillofac Implants. 2018 May/Jun;33(3):565-70. https://doi.org/10.11607/jomi.6238

61. Hayashi M, Nakashima T, Taniguchi M, Kodama T, Kumanogoh A, Takayanagi H. Osteoprotection by semaphorin 3A. Nature. 2012 May;485(7396):69-74. https://doi.org/10.1038/nature11000

62. Tsai CC, Chen HS, Chen SL, Ho YP, Ho KY, Wu YM, et al. Lipid peroxidation: a possible role in the induction and progression of chronic periodontitis. J Periodontal Res. 2005 Oct;40(5):378-84. https://doi.org/10.1111/j.1600-0765.2005.00818.x 
63. Veen BS, Winther MP, Heeringa P. Myeloperoxidase: molecular mechanisms of action and their relevance to human health and disease. Antioxid Redox Signal. 2009 Nov;11(11):2899-937. https://doi.org/10.1089/ars.2009.2538

64. Konttinen YT, Lappalainen R, Laine P, Kitti U, Santavirta S, Teronen O. Immunohistochemical evaluation of inflammatory mediators in failing implants. Int J Periodontics Restorative Dent. 2006 Apr;26(2):135-41.

65. Laine ML, Leonhardt A, Roos-Jansåker AM, Peña AS, van Winkelhoff AJ, Winkel EG, et al. IL-1RN gene polymorphism is associated with peri-implantitis. Clin Oral Implants Res. 2006 Aug;17(4):380-5. https://doi.org/10.1111/i.1600-0501.2006.01249.x

66. Hamdy AA, Ebrahem MA. The effect of interleukin-1 allele 2 genotype (IL-1a(-889) and IL-1b(+3954)) on the individual's susceptibility to peri-implantitis: case-control study. J Oral Implantol. 2011 Jun;37(3):325-34. https://doi.org/10.1563/AAID-JOI-D-09-00117.1

67. Dereka X, Mardas N, Chin S, Petrie A, Donos N. A systematic review on the association between genetic predisposition and dental implant biological complications. Clin Oral Implants Res. 2012 Jul;23(7):775-88. https://doi.org/10.1111/j.1600-0501.2011.02329.x

68. Dos Santos MC, Campos MI, Souza AP, Scarel-Caminaga RM, Mazzonetto R, Line SR. Analysis of the transforming growth factor-beta 1 gene promoter polymorphisms in early osseointegrated implant failure. Implant Dent. 2004 Sep;13(3):262-9. https://doi.org/10.1097/01.id.0000140463.10204.87

69. Campos MI, dos Santos MC, Trevilatto PC, Scarel-Caminaga RM, Bezerra FJ, Line SR. Early failure of dental implants and TNF-alpha (G-308A) gene polymorphism. Implant Dent. 2004 Mar;13(1):95-101. https://doi.org/10.1097/01.ID.0000116458.60585.C4

70. Campos MI, Godoy dos Santos MC, Trevilatto PC, Scarel-Caminaga RM, Bezerra FJ, Line SR. Interleukin-2 and interleukin-6 gene promoter polymorphisms, and early failure of dental implants. Implant Dent. 2005a Dec;14(4):391-6. https://doi.org/10.1097/01.id.0000188470.54417.98

71. Campos MI, Santos MC, Trevilatto PC, Scarel-Caminaga RM, Bezerra FJ, Line SR. Evaluation of the relationship between interleukin-1 gene cluster polymorphisms and early implant failure in non-smoking patients. Clin Oral Implants Res. 2005b Apr;16(2):194-201. https://doi.org/10.1111/i.1600-0501.2004.01091.x

72. Shimpuku H, Nosaka Y, Kawamura T, Tachi Y, Shinohara M, Ohura K. Genetic polymorphisms of the interleukin-1 gene and early marginal bone loss around endosseous dental implants. Clin Oral Implants Res. 2003 Aug;14(4):423-9. https://doi.org/10.1034/j.1600-0501.2003.110823.x

73. Leite MF, Santos MC, de Souza AP, Line SR. Osseointegrated implant failure associated with MMP-1 promotor polymorphisms (-1607 and -519). Int J Oral Maxillofac Implants. 2008 Jul-Aug;23(4):653-8.

74. Rakic M, Petkovic-Curcin A, Struillou X, Matic S, Stamatovic N, Vojvodic D. CD14 and TNF $\alpha$ single nucleotide polymorphisms are candidates for genetic biomarkers of peri-implantitis. Clin Oral Investig. 2015 May;19(4):791-801. https://doi.org/10.1007/s00784-014-1313-3

75. Petkovic-Curcin A, Zeljic K, Cikota-Aleksic B, Dakovic D, Tatic Z, Magic Z. Association of Cytokine Gene Polymorphism with Peri-implantitis Risk. Int J Oral Maxillofac Implants. 2017 Sep/Oct;32(5):e241-8. https://doi.org/10.11607/jomi.5814

76. Rakic M, Struillou X, Petkovic-Curcin A, Matic S, Canullo L, Sanz M, et al. Estimation of bone loss biomarkers as a diagnostic tool for peri-implantitis. J Periodontol. 2014 Nov;85(11):1566-74. https://doi.org/10.1902/jop.2014.140069

77. Moy PK, Medina D, Shetty V, Aghaloo TL. Dental implant failure rates and associated risk factors. Int J Oral Maxillofac Implants. 2005 Jul-Aug;20(4):569-77. PMID:16161741

78. Dowell S, Oates TW, Robinson M. Implant success in people with type 2 diabetes mellitus with varying glycemic control: a pilot study. J Am Dent Assoc. 2007 Mar;138(3):355-61. https://doi.org/10.14219/jada.archive.2007.0168

79. Oates TW, Dowell S, Robinson M, McMahan CA. Glycemic control and implant stabilization in type 2 diabetes mellitus. J Dent Res. 2009 Apr;88(4):367-71. https://doi.org/10.1177/0022034509334203

80. Ribeiro FV, Mendonça AC, Santos VR, Bastos MF, Figueiredo LC, Duarte PM. Cytokines and bone-related factors in systemically healthy patients with chronic periodontitis and patients with type 2 diabetes and chronic periodontitis. J Periodontol. 2011 Aug;82(8):1187-96. https://doi.org/10.1902/jop.2011.100643

81. Nobre MA, Maló P, Gonçalves Y, Sabas A, Salvado F. Outcome of dental implants in diabetic patients with and without cardiovascular disease: A 5-year post-loading retrospective study. Eur J Oral Implantol. 2016;9(1):87-95.

82. Tawil G, Younan R, Azar P, Sleilati G. Conventional and advanced implant treatment in the type II diabetic patient: surgical protocol and long-term clinical results. Int J Oral Maxillofac Implants. 2008 Jul-Aug;23(4):744-52.

83. Jimenez M, Hu FB, Marino M, Li Y, Joshipura KJ. Type 2 diabetes mellitus and 20 year incidence of periodontitis and tooth loss. Diabetes Res Clin Pract. 2012 Dec;98(3):494-500. https://doi.org/10.1016/i.diabres.2012.09.039

84. Renvert S, Aghazadeh A, Hallström H, Persson GR. Factors related to peri-implantitis - a retrospective study. Clin Oral Implants Res. 2014 Apr;25(4):522-9. https://doi.org/10.1111/clr.12208

85. Turri A, Rossetti PH, Canullo L, Grusovin MG, Dahlin C. Prevalence of Peri-implantitis in Medically Compromised Patients and Smokers: A Systematic Review. Int J Oral Maxillofac Implants. 2016 Jan-Feb;31(1):111-8. https://doi.org/10.11607/jomi.4149 
86. Venza I, Visalli M, Cucinotta M, De Grazia G, Teti D, Venza M. Proinflammatory gene expression at chronic periodontitis and peri-implantitis sites in patients with or without type 2 diabetes. J Periodontol. 2010 Jan;81(1):99-108 https://doi.org/10.1902/jop.2009.090358

87. Al-Sowygh ZH, Ghani SM, Sergis K, Vohra F, Akram Z. Peri-implant conditions and levels of advanced glycation end products among patients with different glycemic control. Clin Implant Dent Relat Res. 2018 Jun;20(3):345-51. https://doi.org/10.1111/cid.12584

88. Catalfamo DL, Britten TM, Storch DL, Calderon NL, Sorenson HL, Wallet SM. Hyperglycemia induced and intrinsic alterations in type 2 diabetes-derived osteoclast function. Oral Dis. 2013 Apr;19(3):303-12. https://doi.org/10.1111/odi.12002

89. Alrabiah M, Al-Aali KA, Al-Sowygh ZH, Binmahfooz AM, Mokeem SA, Abduljabbar T. Association of advanced glycation end products with peri-implant inflammation in prediabetes and type 2 diabetes mellitus patients. Clin Implant Dent Relat Res. 2018 Aug;20(4):535-40. https://doi.org/10.1111/cid.12607

90. Yaghobee S, Khorsand A, Paknejad M. Comparison of interleukin-1 $\beta$ levels in gingival crevicular fluid and peri-implant crevicular fluid and its relationship with clinical indexes. J Dent (Tehran). 2013 Jan;10(1):1-9.

91. Ghiraldini B, Conte A, Casarin RC, Casati MZ, Pimentel SP, Cirano FR, et al. Influence of Glycemic Control on Peri-Implant Bone Healing: 12-Month Outcomes of Local Release of Bone-Related Factors and Implant Stabilization in Type 2 Diabetics. Clin Implant Dent Relat Res. 2016 Aug;18(4):801-9. https://doi.org/10.1111/cid.12339

92. Atieh MA, Alsabeeha NH, Faggion CM Jr, Duncan WJ. The frequency of peri-implant diseases: a systematic review and meta-analysis. J Periodontol. 2013 Nov;84(11):1586-98.

93. Saaby M, Karring E, Schou S, Isidor F. Factors influencing severity of peri-implantitis. Clin Oral Implants Res. 2016 Jan;27(1):7-12. https://doi.org/10.1111/clr.12505

94. Ataoglu H, Alptekin NO, Haliloglu S, Gursel M, Ataoglu T, Serpek B, et al. Interleukin-1beta, tumor necrosis factor-alpha levels and neutrophil elastase activity in peri-implant crevicular fluid. Clin Oral Implants Res. 2002 Oct;13(5):470-6. https://doi.org/10.1034/j.1600-0501.2002.130505.x

95. Ryder MI. The influence of smoking on host responses in periodontal infections. Periodontol 2000. 2007;43(1):267-77. https://doi.org/10.1111/j.1600-0757.2006.00163.x

96. Konermann A, Götz W, Le M, Dirk C, Lossdörfer S, Heinemann F. Histopathological Verification of Osteoimmunological Mediators in Peri-Implantitis and Correlation to Bone Loss and Implant Functional Period. J Oral Implantol. 2016 Feb;42(1):61-8. https://doi.org/10.1563/aaid-joi-D-13-00355

97. Negri BM, Pimentel SP, Casati MZ, Cirano FR, Casarin RC, Ribeiro FV. Impact of a chronic smoking habit on the osteoimmunoinflammatory mediators in the peri-implant fluid of clinically healthy dental implants. Arch Oral Biol. 2016 Oct;70:55-61. https://doi.org/10.1016/i.archoralbio.2016.05.014

98. Akram Z, Vohra F, Bukhari IA, Sheikh SA, Javed F. Clinical and radiographic peri-implant parameters and proinflammatory cytokine levels among cigarette smokers, smokeless tobacco users, and nontobacco users. Clin Implant Dent Relat Res. 2018 Feb;20(1):76-81. https://doi.org/10.1111/cid.12575

99. Abduljabbar T, Akram Z, Vohra F, Warnakulasuriya S, Javed F. Assessment of interleukin-1 $\beta$, interleukin- 6 , and tumor necrosis factor- $\alpha$ levels in the peri-implant sulcular fluid among waterpipe (narghile) smokers and never-smokers with peri-implantitis. Clin Implant Dent Relat Res. 2018 Apr;20(2):144-50. https://doi.org/10.1111/cid.12557

100. Vohra F, Alkhudhairy F, Al-Kheraif AA, Akram Z, Javed F. Peri-implant parameters and C-reactive protein levels among patients with different obesity levels. Clin Implant Dent Relat Res. 2018 Apr;20(2):130-6. https://doi.org/10.1111/cid.12556

101. Fretwurst T, Buzanich G, Nahles S, Woelber JP, Riesemeier H, Nelson K. Metal elements in tissue with dental peri-implantitis: a pilot study. Clin Oral Implants Res. 2016 Sep;27(9):1178-86. https://doi.org/10.1111/clr.12718

102. Fretwurst T, Nelson K, Tarnow DP, Wang HL, Giannobile WV. Is Metal Particle Release Associated with Peri-implant Bone Destruction? An Emerging Concept. J Dent Res. 2018 Mar;97(3):259-65. https://doi.org/10.1177/0022034517740560

103. Schwarz F, Sahm N, Mihatovic I, Golubovic V, Becker J. Surgical therapy of advanced ligature-induced peri-implantitis defects: cone-beam computed tomographic and histological analysis. J Clin Periodontol. 2011 Oct;38(10):939-49. https://doi.org/10.1111/j.1600-051X.2011.01739.x

104. Souza JC, Barbosa SL, Ariza EA, Henriques M, Teughels W, Ponthiaux P, et al. How do titanium and Ti6Al4V corrode in fluoridated medium as found in the oral cavity? An in vitro study. Mater Sci Eng C. 2015 Feb;47:384-93. https://doi.org/10.1016/i.msec.2014.11.055

105. Franchi M, Bacchelli B, Martini D, Pasquale VD, Orsini E, Ottani V, et al. Early detachment of titanium particles from various different surfaces of endosseous dental implants. Biomaterials. 2004 May;25(12):2239-46. https://doi.org/10.1016/i.biomaterials.2003.09.017

106. Mabilleau G, Bourdon S, Joly-Guillou ML, Filmon R, Baslé MF, Chappard D. Influence of fluoride, hydrogen peroxide and lactic acid on the corrosion resistance of commercially pure titanium. Acta Biomater. 2006 Jan;2(1):121-9. https://doi.org/10.1016/i.actbio.2005.09.004 
107. Wheelis SE, Gindri IM, Valderrama P, Wilson TG Jr, Huang J, Rodrigues DC. Effects of decontamination solutions on the surface of titanium: investigation of surface morphology, composition, and roughness. Clin Oral Implants Res. 2016 Mar;27(3):329-40. https://doi.org/10.1111/clr.12545

108. Noronha Oliveira M, Schunemann WV, Mathew MT, Henriques B, Magini RS, Teughels W, et al. Can degradation products released from dental implants affect peri-implant tissues? J Periodontal Res. 2018 Feb;53(1):1-11. https://doi.org/10.1111/ire.12479

109. Pettersson M, Kelk P, Belibasakis GN, Bylund D, Molin Thorén M, Johansson A. Titanium ions form particles that activate and execute interleukin-1 $\beta$ release from lipopolysaccharide-primed macrophages. J Periodontal Res. 2017 Feb;52(1):21-32. https://doi.org/10.1111/ire.12364

110. Caicedo MS, Pennekamp PH, McAllister K, Jacobs JJ, Hallab NJ. Soluble ions more than particulate cobalt-alloy implant debris induce monocyte costimulatory molecule expression and release of proinflammatory cytokines critical to metal-induced lymphocyte reactivity. J Biomed Mater Res A. 2010 Jun;93(4):1312-21.

111. Wachi T, Shuto T, Shinohara Y, Matono Y, Makihira S. Release of titanium ions from an implant surface and their effect on cytokine production related to alveolar bone resorption. Toxicology. 2015 Jan;327:1-9. https://doi.org/10.1016/i.tox.2014.10.016

112. Taira M, Sasaki K, Saitoh S, Nezu T, Sasaki M, Kimura S, et al. Accumulation of element Ti in macrophage-like RAW264 cells cultured in medium with 1 ppm Ti and effects on cell viability, SOD production and TNF-alpha secretion. Dent Mater J. 2006 Dec;25(4):726-32. https://doi.org/10.4012/dmi.25.726 